\title{
The effect of zinc ions on fertilization of mouse ova in vitro
}

\author{
S. Aonuma, M. Okabe and M. Kawaguchi
}

\author{
Faculty of Pharmaceutical Sciences, Osaka University, 133-1 Yamadakami, Suitashi, Osaka, Japan
}

\begin{abstract}
Summary. The fertilization rate of mouse gametes in a Krebs-Ringer bicarbonate medium was $60 \%$. The rate fell to $0 \%$ when $250 \mu \mathrm{M}-\mathrm{ZnCl}_{2}$ was added, but $\mathrm{MgCl}_{2}$, $\mathrm{CaCl}_{2}, \mathrm{MnCl}_{2}, \mathrm{FeCl}_{2}$ and $\mathrm{CuCl}_{2}$ (each at $250 \mu \mathrm{M}$ ) had no effect. The inhibitory effect of $\mathrm{Zn}^{2+}$ was not evident if the spermatozoa or eggs were preincubated with $\mathrm{Zn}^{2+}$ or if previously capacitated spermatozoa were used. The $\mathrm{Zn}^{2+}$ is thought to act by interference with capacitation.
\end{abstract}

\section{Introduction}

Bertrand \& Vladesco (1921), aware of the relatively large amounts of zinc in the prostate gland, testes and semen of mammals, postulated that the element might play an important role in reproduction. Others have also noted that semen and spermatozoa are rich sources of zinc (Mann, 1945; Mawson \& Fischer, 1953; Fujii, Utida \& Mizuno, 1955). Zinc is known to exist in many metallo-enzymes ( $\mathrm{Li}$, 1966), some of which occur in the prostate gland or spermatozoa, e.g. carbonic anhydrase, nonspecific acid and alkaline phosphatase and 5'-nucleotidase (Mann, 1964). However, all the zinc in semen cannot be explained from the amounts of these enzymes. The succinate-induced enhancement of the respiratory activity of human spermatozoa is known to be counteracted by $\mathrm{Zn}^{2+}$ (Eliasson, Johnsen \& Lindholmer, 1971), and EDTA, histidine or cysteine treatment of human spermatozoa causes release of $\mathrm{Zn}^{2+}$ and an increase of oxygen uptake by and motility of the spermatozoa (Huacuja, Sosa, Delgado \& Rosado, 1973). The spermatozoa of several species can be successfully capacitated in vitro (Toyoda, Yokoyama \& Hoshi, 1971; Bavister, 1973; Toyoda \& Chang, 1974; Brackett \& Oliphant, 1975) and seminal plasma is known to contain decapacitating activity (Chang, 1957; Bedford \& Chang, 1962; Weinmann \& Williams, 1964; Dukelow, Chernoff \& Williams, 1966; Pinsker \& Williams, 1967), but the involvement of $\mathrm{Zn}^{2+}$ in capacitation and decapacitation phenomena has not been examined. The purpose of the present study was to investigate the effect of adding $\mathrm{Zn}^{2+}$ to the medium on the fertilization of mouse ova in vitro.

\section{Materials and Methods}

\section{Preparation of sperm suspension and ova}

The standard medium used throughout the experiments was a modified Krebs-Ringer bicarbonate (m-KRB) solution (Toyoda, Yokoyama \& Hoshi, 1971). The amount of $\mathrm{NaHCO}_{3}$ was increased from 2.01 to $5.00 \mathrm{~g} / \mathrm{l}$ to bring the $\mathrm{pH}$ from 7.4 to 8.0 , a value shown to be more suitable for in-vitro fertilization of mouse ova in our laboratory (Aonuma, Okabe \& Kawai, 1976).

The ova were obtained from immature ddy female mice, 4-5 weeks old, which were injected intraperitoneally with 5 i.u. PMSG (Teikoku Zoki) $48 \mathrm{~h}$ before an i.p. injection of 5 i.u. hCG (Teikoku Zoki). The mice were killed $14-16 \mathrm{~h}$ after the $\mathrm{hCG}$ injection and the oviducts were removed and placed in $5 \mathrm{ml} \mathrm{m-KRB}$ in a watch-glass. The ova were released from the oviduct ampullae, washed twice with medium, and were introduced to $0.4 \mathrm{ml} \mathrm{m}-\mathrm{KRB}$ (or m-KRB containing additional divalent cations) under paraffin oil in glass test-tubes $(12 \times 100 \mathrm{~mm})$ and maintained at $37^{\circ} \mathrm{C}$. 
Epididymal spermatozoa were obtained from mice weighing $30-40 \mathrm{~g}$. The connective tissues, blood vessels and fat pad over the cauda epididymidis were cut away and the spermatozoa were extruded from slits in the tubules into $2 \mathrm{ml} \mathrm{m}-\mathrm{KRB}$ which had been previously equilibrated with $5 \%$ $\mathrm{CO}_{2}$ in air. After $3 \mathrm{~min}, 1 \mathrm{ml}$ sperm suspension was removed from the surface of the mixture: sperm concentration was $1.0-1.5 \times 10^{6} / \mathrm{ml}$. For the experiments, $50 \mu \mathrm{l}$ aliquots of the uncapacitated or capacitated sperm suspension (capacitated spermatozoa were obtained by incubating epididymal spermatozoa in $\mathrm{m}-\mathrm{KRB}$ for $40 \mathrm{~min}$ at $37^{\circ} \mathrm{C}$ (Aonuma et al., 1976)) were added to $0.4 \mathrm{ml} \mathrm{m}-\mathrm{KRB}$ containing 15-20 ova.

\section{Effect of divalent cations}

Solutions of $\mathrm{ZnCl}_{2}, \mathrm{MgCl}_{2}, \mathrm{CaCl}_{2}, \mathrm{MnCl}_{2}, \mathrm{FeCl}_{2}, \mathrm{CuCl}_{2}$ and $\mathrm{HgCl}_{2}$ were prepared in distilled water to a concentration of $5 \mathrm{~mm}$. Calculated amounts of these stock solutions were added to the $\mathrm{m}-\mathrm{KRB}$ to give the required concentrations of divalent cations for examination of their effects on fertilization of mouse ova in vitro.

In Exp. I, the ova were placed in $0.4 \mathrm{ml} \mathrm{m}-\mathrm{KRB}$ containing $5-250 \mu \mathrm{M}-\mathrm{ZnCl}_{2}$ or $250 \mu \mathrm{M}-\mathrm{MgCl}_{2}$, $\mathrm{CaCl}_{2}, \mathrm{MnCl}_{2}, \mathrm{FeCl}_{2}, \mathrm{CuCl}_{2}$ or $\mathrm{HgCl}_{2}$. In Exp. II the ova were placed in $0.4 \mathrm{ml} \mathrm{m}-\mathrm{KRB}$ containing $250 \mu \mathrm{M}-\mathrm{ZnCl}_{2}(\mathrm{Zn}-\mathrm{KRB})$ and incubated with capacitated spermatozoa. In Exp. III, the ova were preincubated in $0.4 \mathrm{ml} \mathrm{Zn-KRB}$ for $30-60 \mathrm{~min}$, washed twice in $\mathrm{m}-\mathrm{KRB}$ and incubated in $0.4 \mathrm{ml}$ $\mathrm{m}-\mathrm{KRB}$ with epididymal spermatozoa. Because the epididymal spermatozoa needed to become capacitated before they could penetrate the eggs, the duration of their exposure to $\mathrm{Zn}^{2+}$ in Exps I and II was different. The effect of prolonged exposure of capacitated spermatozoa to $\mathrm{Zn}^{2+}$ was therefore examined. In Exp. IV, spermatozoa were incubated in $\mathrm{Zn}-\mathrm{KRB}$ for $40 \mathrm{~min}$ before incubation with ova in $\mathrm{m}-\mathrm{KRB}$. In Exp. $\mathrm{V}, \mathrm{ZnCl}_{2}$ was added to the suspension of capacitated spermatozoa to give a concentration of $250 \mu \mathrm{M}-\mathrm{ZnCl}_{2}$. The spermatozoa were incubated for a further $40 \mathrm{~min}$ before addition to ova in $\mathrm{Zn}-\mathrm{KRB}$.

In all the experiments the ova were incubated with spermatozoa for $90 \mathrm{~min}$ at $37^{\circ} \mathrm{C}$ under $5 \% \mathrm{CO}_{2}$ in air. They were treated with $0.01 \%$ hyaluronidase (Sigma) for $5 \mathrm{~min}$ and examined for the penetration of spermatozoa.

\section{Results}

The addition of $\mathrm{Zn}^{2+}$ to the medium inhibited sperm penetration through the zona pellucida slightly at $30 \mu \mathrm{M}$ and completely at $250 \mu \mathrm{M}$ (Table 1$)$.

Table 1. The effect (mean \pm s.e.m. of 3-6 independent tests) of various concentrations of $\mathrm{Zn}^{2+}$ on the fertilization of mouse ova

\begin{tabular}{lccccrrrr}
\hline & \multicolumn{7}{c}{$\mathrm{Zn}^{2+}$ conc. $(\mu \mathrm{M})$} \\
\cline { 2 - 8 } & 0 & $7 \cdot 8$ & $15 \cdot 6$ & $31 \cdot 3$ & $62 \cdot 5$ & 125 & 250 & 500 \\
\hline No. of replicates & 6 & 3 & 3 & 3 & 6 & 6 & 6 & 3 \\
Total no. of ova examined & 104 & 59 & 66 & 66 & 108 & 113 & 95 & 53 \\
Ova penetrated $(\%)$ & $54 \pm 6$ & $56 \pm 5$ & $56 \pm 2$ & $35 \pm 8$ & $14 \pm 3$ & $7 \pm 3$ & 0 & 0 \\
\hline
\end{tabular}

As shown in Table 2, $\mathrm{Hg}^{2+}$ also caused complete inhibition of fertilization in vitro. Moreover, after treatment with $\mathrm{Hg}^{2+}$, but not with $\mathrm{Zn}^{2+}$, the spermatozoa became immotile and the vitellus became darkened and opaque. The inhibitory effect by $\mathrm{Cu}^{2+}$ could not be regarded as significant. 
Table 2. Effect (mean \pm s.e.m. of values in 3 independent tests) of various divalent cations on the fertilization of mouse ova in vitro

\begin{tabular}{ccc}
\hline Cation & $\begin{array}{c}\text { Total no. of } \\
\text { ova examined }\end{array}$ & Ova penetrated (\%) \\
\hline- & 52 & $60 \pm 9$ \\
$\mathrm{Zn}^{2+}$ & 45 & $67 \pm 4$ \\
$\mathrm{Mg}^{2+}$ & 53 & $59 \pm 9$ \\
$\mathrm{Ca}^{2+}$ & 48 & $52 \pm 10$ \\
$\mathrm{Mn}^{2+}$ & 56 & $67 \pm 8$ \\
$\mathrm{Fe}^{2+}$ & 57 & $32 \pm 13$ \\
$\mathrm{Cu}^{2+}$ & 46 & 0 \\
$\mathrm{Hg}^{2+}$ & 20 & \\
\hline
\end{tabular}

* Each at $250 \mu \mathrm{M}$ in $\mathrm{m}-\mathrm{KRB}$ containing $1.19 \mathrm{mM}-\mathrm{Mg}^{2+}$ and $1.71 \mathrm{mM}-\mathrm{Ca}^{2+}$, except when these ions were increased as shown.

Table 3. Effect (mean \pm s.e.m. of values in 3-5 independent tests) of $\mathrm{Zn}^{2+}$ on the fertilization of mouse ova in vitro under various conditions

\begin{tabular}{lllcccc}
\hline Treatment* & Spermatozoa & Ova & $\begin{array}{c}\mathrm{Zn}^{2+} \text { in final } \\
\text { culture medium }\end{array}$ & $\begin{array}{c}\text { No. of } \\
\text { replicates }\end{array}$ & $\begin{array}{c}\text { Total no. of } \\
\text { ova examined }\end{array}$ & Ova penetrated (\%) \\
\hline None & Epididymal & Normal & - & 4 & 88 & $68 \pm 7$ \\
$\mathrm{Zn}^{2+}$ & & & & & \\
Exp. I & Epididymal & Normal & + & 4 & 81 & 0 \\
Exp. II & Capacitated & Normal & + & 5 & 109 & $59 \pm 8$ \\
Exp. III & Epididymal & Treated & - & 4 & 77 & $54 \pm 9$ \\
Exp. IV & $\begin{array}{c}\text { Treated } \\
\text { epididymal }\end{array}$ & Normal & - & 3 & 52 & $52 \pm 10$ \\
Exp. V & $\begin{array}{c}\text { Treated } \\
\text { capacitated }\end{array}$ & Normal & + & 3 & 51 & $38 \pm 11$ \\
\hline
\end{tabular}

* See 'Materials and Methods': 'treated' represents preincubation in $250 \mu \mathrm{M}-\mathrm{Zn}^{2+}$.

Table 4. Relationship between mouse sperm capacitation and $\mathrm{Zn}^{2+}$

\begin{tabular}{lcc}
\hline & \multicolumn{2}{c}{ Incubation time after insemination (min) } \\
\cline { 2 - 3 } & 30 & 90 \\
\hline Epididymal spermatozoa & 0 & $64 \pm 13$ \\
Capacitated spermatozoa & $58 \pm 10$ & $59 \pm 8$ \\
Treated spermatozoa* & $2 \pm 2$ & $52 \pm 10$ \\
\hline
\end{tabular}

Values represent the \% of ova penetrated (mean \pm s.e.m. of values in 3 independent replicates).

* Preincubated with $250 \mu \mathrm{M}-\mathrm{Zn}^{2+}$ for $40 \mathrm{~min}$.

As shown in Table 3, the numbers of eggs fertilized were not influenced by any of the treatments of Exps II-V. $\mathrm{Zn}^{2+}$ no longer inhibited fertilization when capacitated spermatozoa were added to ova (Exp. II).

The time of zona penetration by the spermatozoa preincubated with $\mathrm{Zn}^{2+}$ for 40 min was compared with that of epididymal or capacitated spermatozoa (Table 4). 


\section{Discussion}

Eliasson et al. (1971) reported that the increased respiratory activity of human spermatozoa which occurs in some conditions can be prevented by treatment with seminal plasma or by the addition of $\mathrm{Zn}^{2+}$ to the medium. The present study showed that the fertilizing ability of mouse capacitated spermatozoa cannot be depressed to the level similar to that of epididymal spermatozoa even after incubation for $40 \mathrm{~min}$ (Table 3). Therefore the inhibitory activity of $\mathrm{Zn}^{2+}$ on fertilization is not due to inhibition of sperm penetration, but to inhibition of sperm capacitation. Spermatozoa preincubated in the presence of $\mathrm{Zn}^{2+}$ were capacitated during subsequent incubation by decreasing the $\mathrm{Zn}^{2+}$ concentration (Exp. IV). The zona penetration by such spermatozoa was similar to that of epididymal spermatozoa in time (Table 4) and in the penetration ratio (Table 3). These results suggest that the fertilizing ability of epididymal spermatozoa was maintained but latent during incubation in the presence of $250 \mu \mathrm{M}-\mathrm{Zn}^{2+}$.

Zinc concentrations in seminal plasma have been reported as $2.06 \mathrm{~mm}$ in man (Mawson \& Fischer, 1953), $349 \mu \mathrm{m}$ in boar (Boursnell, Baronos, Briggs \& Butler, 1972), $1.04 \mathrm{~mm}$ in dog (Saito, Zeitz, Bush, Lee \& Whitmore, 1969) and $600 \mu \mathrm{M}$ in rabbit (S. Aonuma, unpublished). Although the $\mathrm{Zn}^{2+}$ concentration in mouse seminal plasma is not known, the concentration of $250 \mu \mathrm{M}-\mathrm{Zn}^{2+}$ used in the present experiments may not differ greatly from that physiologically available in the seminal plasma of the mouse.

Although the decapacitating activity of $\mathrm{Zn}^{2+}$ was not observed at $250 \mu \mathrm{M}$, the nature of the capacitation inhibitory activity of $\mathrm{Zn}^{2+}$ (which was not observed for $\mathrm{Mg}^{2+}, \mathrm{Ca}^{2+}, \mathrm{Fe}^{2+}$ and $\mathrm{Cu}^{2+}$ ) described in this paper suggests that $\mathrm{Zn}^{2+}$ may play an important role, at least in vitro, in the regulation of fertilizing ability of spermatozoa, other than that of the decapacitation factor(s) found in seminal plasma (Chang, 1957), epididymal fluid (Weinman \& Williams, 1964) or spermatozoa (Aonuma et al., 1973).

It is widely accepted that capacitation may represent a change in the sperm membrane (Austin \& Bavister, 1975). However, the functional groups of macromolecular components of biological membranes might react differently with metals when there is a change in membrane stability (Wills \& Wilkinson, 1967; Chvapil, Ryan \& Zukoski, 1972; Chvapil, 1973). Whether or not the capacitation inhibitory effect by $\mathrm{Zn}^{2+}$ described in the present report is related to the stability of the sperm membrane, it seems important that the participation of zinc is taken into account in studies of the functional properties of spermatozoa.

\section{References}

Aonuma, S., OKabe, M. \& Kawai, Y. (1976) In vitro fertilization of mouse ova I. J. Pharm. Soc. Japan, 96, 1307-1312.

Aonuma, S., Mayumi, T., Suzuki, K., Noguchi, T., IWAI, M. \& OKabe, M. (1973) Studies on sperm capacitation. I. The relationship between a guinea-pig sperm-coating antigen and a sperm capacitation phenomenon. J. Reprod. Fert. 35, 425-432.

Austin, C.R. \& Bavister, B.D. (1975) Preliminaries to the acrosome reaction in mammalian spermatozoa. In Functional Anatomy of the Spermatozoon, pp. 8387. Ed. B. A. Afzelius. Pergamon Press, New York.

Bavister, B.D. (1973) Capacitation of golden hamster spermatozoa during incubation in culture medium. J. Reprod. Fert. 35, 161-163.

Bedford, J.M. \& Chang, M.C. (1962) Removal of decapacitation factor from seminal plasma by high speed centrifugation. Am.J. Physiol. 202, 179-181.
Bertrand, G. \& Vladesco, M.R. (1921) Intervention probable du zinc dans les phénomenès de fécondation chez les animaux vertèbres. C. r. hebd. Séanc. Acad. Sci., Paris 173, 176-179.

Boursnell, J.C., Baronos, S., Briggs, P.A. \& Butler, E.J. (1972) The concentration of zinc in boar seminal plasma and vesicular secretion in relation to those of nitrogenous substances, citrate, galactose and fructose. J. Reprod. Fert. 29, 215-227.

Brackett, B.G. \& Oliphant, G. (1975) Capacitation of rabbit spermatozoa in vitro. Biol. Reprod. 12, 260 274.

Chang, M.C. (1957) A detrimental effect of rabbit seminal plasma on the fertilizing capacity of sperm. Nature, Lond. 179, 258-259.

Chvapil, M. (1973) New aspects in the biological role of zinc: a stabilizer of macromolecules and biological membranes. Life Sci. 13, 1041-1049. 
Chyapil, M., Ryan, J.N. \& Zukoskı, C.F. (1972) The effect of zinc and other metals on stability of lysosomes. Proc. Soc. exp. Biol. Med. 140, 642-646.

Dukelow, W.R., Chernoff, H.N. \& Williams, W.L. (1966) Enzymatic characterization of decapacitation factors. Proc. Soc. exp. Biol. Med. 121, 396-398.

Eliasson, R., Johnsen, O. \& Lindholmer, C. (1971) Effect of zinc on human sperm respiration Life Sci. 10, 1317-1320.

Fujil, T., Utida, S. \& Mizuno, T. (1955) Reaction of starfish spermatozoa to histidine and certain other substances considered in relation to zinc. Nature, Lond. 176, 1068-1069.

Huacuja, L., Sosa, A., Delgado, N.M. \& Rosado, A. (1973) A kinetic study of the participation of zinc in human spermatozoa metabolism. Life Sci. 13, 13831394.

L1, T.K. (1966) Functional role of zinc in metalloenzymes. In Zinc Metabolism, pp. 48-68. Ed. A.S. Prasad. Charles C. Thomas, Springfield, Illinois.

MaNN, T. (1945) The metabolism of semen. I. General aspects. Occurrence and distribution of cytochrome, certain enzymes and coenzymes. Biochem.J. 39, 451458.
ManN, T. (1964) The Biochemistry of Semen and of the Male Reproductive Tract, p. 161. Methuen, London.

MAwson, C.A. \& Fischer, M.I. (1953) Zinc and carbonic anhydrase in human semen. Biochem. J. 55, 696-700.

Pinsker, M.C. \& Williams, W.L. (1967) Properties of a spermatozoan anti-fertility factor. Archs Biochem. Biophys. 122, 111-117.

Saito, S., Zeitz, L., Bush, I.M., Lee, R. \& Whitmore, W.F. (1969) Zinc uptake in canine or rat spermatozoa. Am. J. Physiol. 217, 1039-1043.

Toyoda, Y. \& ChaNG, M.C. (1974) Fertilization of rat eggs in vitro by epididymal spermatozoa and the development of eggs following transfer. $J$. Reprod. Fert. 36, 9-22.

Toyoda, Y., Yokoyama, M. \& Hoshi, T. (1971) Studies on the fertilization of mouse eggs in vitro. 1 . In vitro fertilization of eggs by fresh epididymal sperm. Jap.J. Anim. Reprod. 16, 147-151.

Weinman, D.E. \& Williams, W.L. (1964) Mechanism of capacitation of rabbit spermatozoa. Nature, Lond. 203, 423-424.

WILls, E.D. \& Wilkinson, A.E. (1967) The effect of irradiation on subcellular particles. Destruction of sulfhydryl groups. Int. J. Radiat. Biol. 13, 45-55.

Received 29 December 1977 